\title{
Health financing policies in Sub-Saharan Africa: government ownership or donors' influence? A scoping review of policymaking processes
}

Lara Gautier ${ }^{1,2,3^{*}}$ and Valéry Ridde ${ }^{1,2}$

\begin{abstract}
Background: The rise on the international scene of advocacy for universal health coverage (UHC) was accompanied by the promotion of a variety of health financing policies. Major donors presented health insurance, user fee exemption, and results-based financing policies as relevant instruments for achieving UHC in Sub-Saharan Africa. The "donor-driven" push for policies aiming at UHC raises concerns about governments' effective buy-in of such policies. Because the latter has implications on the success of such policies, we searched for evidence of government ownership of the policymaking process.

Methods: We conducted a scoping review of the English and French literature from January 2001 to December 2015 on government ownership of decision-making on policies aiming at UHC in Sub-Saharan Africa. Thirty-five (35) results were retrieved. We extracted, synthesized and analyzed data in order to provide insights on ownership at five stages of the policymaking process: emergence, formulation, funding, implementation, and evaluation.

Results: The majority of articles (24/35) showed mixed results (i.e. ownership was identified at one or more levels of policymaking process but not all) in terms of government ownership. Authors of only five papers provided evidence of ownership at all reviewed policymaking stages. When results demonstrated some lack of government ownership at any of the five stages, we noticed that donors did not necessarily play a role: other actors' involvement was contributing to undermining government-owned decision-making, such as the private sector. We also found evidence that both government ownership and donors' influence can successfully coexist.

Discussion: Future research should look beyond indicators of government ownership, by analyzing historical factors behind the imbalance of power between the different actors during policy negotiations. There is a need to investigate how some national actors become policy champions and thereby influence policy formulation. In order to effectively achieve government ownership of financing policies aiming at UHC, we recommend strengthening the State's coordination and domestic funding mobilization roles, together with securing a higher involvement of governmental (both political and technical) actors by donors.
\end{abstract}

\footnotetext{
* Correspondence: lara.gautier@umontreal.ca

'Department of social and preventive medicine, School of Public Health,

Université de Montréal, Montréal, Québec, Canada

${ }^{2}$ Public Health Research Institute (IRSPUM), Université de Montréal, Montréal,

Québec, Canada

Full list of author information is available at the end of the article
} 


\section{Background}

Over the past few years, and especially since the publication of the 2010 World Health Report (WHR) [1], universal health coverage (UHC) has generated a wide consensus at the international level [2-5]. As per World Health Organization (WHO)'s online factsheet, UHC aims at reaching a balance between extending access to healthcare services to all people, ensuring affordability for all people, and improving quality of care [6]. In the 2010s, there was a more explicit push for UHC, to the point of being officially included as an official target of the Sustainable Development Goals for 2016-2030 [7]. Initially focusing on financing mechanisms, this global movement $[8,9]$ produced a restricted understanding of $\mathrm{UHC}$ and resulted in overlooking issues related to equity and quality of care [5]. The rise on the international scene of advocacy for UHC was thus accompanied by the promotion of new health financing policies (e.g., health insurance, user fee exemption, and results-based financing), which donors presented as relevant instruments for achieving UHC [10].

\section{Financing policies aiming at UHC}

Health insurance in its various forms (community-based health insurance, national insurance schemes, etc.) was introduced in the African landscape about 20 years ago [11]. Health insurance aims to improve financial access to health care (of those affiliated) through a reduction of patients' direct payments. Another strategy to increase demand is the abolition of the direct payment for care (or "user fee exemption") for certain services or specific categories of population. By curbing out-of-pocket expenditures, this strategy is set to improve financial access to health services. It emerged in the mid-2000s in response to the negative effects of cost recovery established in the early 1990s under the leadership of the World Bank and UNICEF [12]. Results-based financing (RBF) "encompasses the entire range of financial incentive approaches on both the demand and the supply sides" [13], including, mainly: conditional cash transfers (CCTs), performance-based financing (PBF), and performance-based contracting (i.e., a form of supplyside incentive used by donors). CCTs are demand-side incentives, providing cash rewards to target populations for "consuming certain social services" [13]. Globally, PBF emerged in the late 2000s around the idea - promoted by donors [14] - that it would help to improve access to quality health services. PBF is based on the transfer of financial resources conditional to achieving pre-agreed targets relating to health providers' or managers' performance [13]. International organizations have framed PBF in the language of "strategic purchasing" for $\mathrm{UHC}[15,16]$. The promotion of UHC has led to the increased implementation of these three financing policies since 2010, particularly in Sub-Saharan Africa [17] - this is the reason for choosing said region as the geographical focus of this review.

These policies have generated mixed results in terms of increased use and quality of healthcare [18-21]. Ownership, defined as "an attitude of accepting responsibility for something and taking control of how it develops" [22], can yield positive results. For instance, it can aid in eliminating barriers to access to care [23]. The mixed results achieved by these policies may be attributable to their "top-down" nature, reflecting the possibility that donor-driven policies do not necessarily fit local contexts [24], and therefore lack buy-in from governments.

\section{Genesis of the concept of "ownership"}

Global health decision-making primarily involves a wide variety of donors [25] including bilateral, multilateral agencies, and international financial institutions (IFIs), as well as non-state actors (inter alia, non-governmental organizations and private-for-profit entities). In this context, the political voice and power of developing nations' governments tend to be limited [26-28]. The high dependence of Sub-Saharan African countries to foreign aid reinforces this tendency. In 2008 external sources provided more than $20 \%$ of total health expenditure in nearly half $(48 \%)$ of the 46 countries in the WHO African Region [29]. Consequently, various development actors and scholars began to call for the reshaping of global governance towards a better inclusion of developing countries, or "Southern" actors [25, 30, 31]. The idea materialized around the promotion of "ownership" by countries from the South [32, 33].

Originally, for IFIs, “ownership" implied limiting the resistance opposed by Southern governments as well as enhancing their liability so as to ensure good behavior of debitors [34]. Ownership of the policy by debitor governments became indispensable to the IFIs who needed a return on investments [35]. The prospect clearly remained that of the donors, whose priority was to "hedge their own political risk" rather than to foster inclusion of recipient countries in policymaking [36].

In spite of their criticism of conditionality, scholars perceived the IFI's approach as a first step towards actual ownership by Southern governments [32, 37]. They refer here to "national ownership" and "government ownership". Woll argues that national ownership "implies a broad-based consensus in a [country's] society at large", while "government ownership" means the government effectively controls the content, implements programs, and secures the commitment of political and administrative elites [38]. The concept of government ownership applies to Foucault and the construction of biopower in the South [28]. Yet this concept did not win donors' support [36]. Indeed, the 2005 Paris Declaration for Aid 
Effectiveness endorsed the concept of "country ownership", whereby recipient governments were simply invited to "exercise leadership in developing and implementing their national development strategies", establish their own systems for donor coordination, and accept only assistance that meets their needs [39]. Exercising leadership is only a mild version of taking actual control over a policy. Importantly, "country ownership" introduces a new ingredient: consultation with civil society and non-governmental organizations (NGOs) [40]. However, in the absence of any guidance "as to who specifically should be involved in what activities" [41], such participatory process led to dissolving responsibilities and diminishing the role of governments. Today, country ownership is still depicted as an inconsistent and "underspecified" term [41]. Some scholars even consider it "misleading" [42]. Because the definition of "government ownership" is more straightforward and in accordance with our vision of more equitable global public health governance, we chose to use this concept in our review.

\section{Definition of the research question}

Improving government ownership is one key strategy envisioned by academics to rebalance global governance for health [25, 32]. Indeed, government's buy-in has obvious implications for the success of global health policies $[43,44]$. In this research, the terms "government" and "State" are used interchangeably: they refer to the highest level of political power in a given country. There is little knowledge about what the concept of ownership means for the recipient countries themselves, and how they put it into practice [36]. Based on a rapid review of the concept, we identify four main indicators of government ownership: political commitment by demonstrating leadership at the highest levels of government [34, 45], effective engagement of technical levels of government $[46,47]$, ability of the government to coordinate international actors within public bodies [45, 48-50], and the government's mobilization of domestic resources to finance the policy in the long term $[48,51]$. Because the UHC goal will continue to gain global traction, we critically assessed the extent to which recipient countries have owned financing policies aiming to achieve this goal. We examined the presence of indicators of government ownership at different phases of decision-making for policies aiming at UHC (detailed below) and investigated whether and how donors influenced this process [52, 53].

\section{Methods}

Mays and colleagues assert that scoping reviews are useful to "map key concepts underpinning a research area [...], and [are rapidly] undertaken as stand-alone projects in their own right, especially where an area is complex or has not been reviewed comprehensively before" [54]. This type of literature reviews adequately fits our research interests: we investigated how the concept of ownership materializes along the policymaking process. We performed a scoping review which takes the form of a transparent mixed studies review of the empirical (quantitative, qualitative, and mixed methods designs) peer-reviewed literature in English and French, from January 2001 (following the implementation of the Millennium Development Goals that entailed many health reforms including those presented above in 1.1) to December 2015 (15year timespan), on Sub-Saharan African (SSA) governments' ownership of health financing policies to attain UHC. Four major scientific databases were looked upon: Medline/Pubmed, EBSCOHost, and Web of Science (for English literature), and CAIRN database (for French literature).

We followed the step-by-step approach for performing scoping reviews developed by Arksey \& O'Malley in 2005 [55] and improved in 2010 by Levac, Colquhoun, and O'Brien [56].

\section{Search strategy}

We provided the full list of keywords as Additional file 1 . We sought to use as many variances as possible of the keywords (e.g., synonyms of "country ownership") in order to make sure that we would cover the relevant papers.

\section{Selecting the relevant papers}

The first author screened initial results' titles and abstracts and excluded those that did not fall in our inclusion criteria (Table 1).

Table 1 List of inclusion criteria

Inclusion criteria

Peer-reviewed papers that were published between January 2001 and December 2015

Peer-reviewed papers examining policymaking processes implemented after 2000

Full text of peer-reviewed papers available in French- or English-language

Peer-reviewed papers that specifically targeted one or several SSA countries

Peer-reviewed papers focusing on public policies of health insurance (community or national schemes), user fee exemption, and results-based financing

Peer-reviewed papers showing a strong (i.e., main topic of the paper) or moderate (i.e., secondary topic or sub-section of the paper) focus on strategies for government ownership of policies aiming at UHC

Peer-reviewed papers with a strong methodological background and/or providing useful findings directly related to government ownership 


\section{Charting the data}

Once we selected the final results, we developed a data extraction form on Excel as a systematic tool to collect the relevant data for our study (see Table 2). The form is available upon request.

\section{Collating, summarizing and reporting the results}

Based on Pluye \& Hong's methodology for conducting mixed studies review and classification of analytical designs [57], we chose the convergent design. All included studies were synthesized qualitatively by the first author. The framework developed by Rocher [58] guided our analysis of the results. Rocher's original framework, largely inspired by the traditional public policy cycle [59], covers actors involved in the following steps of policymaking: conceptualization, promotion, formulation, funding, and implementation. For the sake of convenience, we merged conceptualization and promotion, and added another stage: policy evaluation - which is traditionally part of the policy cycle, yet rarely investigated in global health policy [60]. Our final themes are the following: emergence (1), formulation (2), funding (3), implementation (4), evaluation (5). The five themes are defined in Table 3. Despite the limitations of the heuristic framework [61], which conceptualized policymaking as a linear process, we chose to use this approach because it enabled us to easily identify indicators of government ownership and/or donors' influence at each stage.

We searched for occurrence of one or more core indicators of government ownership at each policymaking stage. Based on this investigation, we assessed each phase as owned (evidence of ownership indicators based on

Table 2 Categories of information in the data extraction form Author and year of publication

Type of paper (original research article, systematic review, conference proceedings), focus country(ies)

Magnitude of the focus on country ownership (strong: main topic of the paper, or moderate: secondary topic or sub-section of the paper)

Focus health financing polic(ies) (user fee exemption, health insurance,...)

Description of the main topic of investigation

Study design (qualitative, quantitative, mixed methods)

Methods used (case study, stakeholders analysis, literature review, etc.)

Findings at the emergence stage

Findings at the formulation stage

Findings at the funding stage

Findings at the implementation stage

Findings at the evaluation stage

Results on overall government ownership

Discussion and observations notes selected papers' findings), not owned (lack of evidence), or owned to a certain extent (mixed evidence). Mixed evidence meant that there were some indicators of ownership at a given policy stage but not all of them.

Finally, we looked at the overall ownership of policies' decision-making process by combining the results of each reviewed stage. The results were assessed based on the five policymaking themes and this last "overall ownership" theme (i.e., six themes in total), which are also represented in the categories of our data extraction as shown above.

\section{Results}

Out of the 848 papers (of which, 257 duplicates were removed) found on scientific databases, we pre-selected 76 papers based on their title and abstract. After reading their full text, we excluded 41 papers because their content did not match our review goals. Details of exclusion are provided in Table 4.

We selected a total of 35 (30 English-language and five French-language) peer-reviewed papers (see Fig. 1).

\section{Information on background and methods of the selected papers}

Details about country and policy representation in the literature are available in Table 5. In country-specific papers, the most frequent countries of study were Ghana [105-110] and Burkina Faso [107, 110-114] (each $N=6$ ).

Performance-based financing (PBF) is the only RBF policy represented in our selection. The majority of selected articles had a strong emphasis on government ownership of policies aiming at UHC $(N=22)$. The remaining 13 articles had only a moderate focus on this theme but still provided useful insights for this review. Table 6 provides additional background information.

Data collection included semi-structured in-depth interviews, focus group discussions, participant observation, and documentation review. When provided by the authors, analytical design was mostly stakeholders' analysis $(N=4)$ [115-118], specific theory-based frameworks $[106,108,119]$, or self-constructed frameworks [120]. Two quantitative papers were casecontrol studies using descriptive statistics with data obtained from questionnaire-based surveys [121, 122]. A third paper reviewed quantitative outcome records without using statistical analysis [123]. Despite their low methodological quality (i.e., very few details given about data collection and analysis), we included a couple of papers because they still provided useful information for our review [106, 111].

As shown in Table 7, only four papers looked into each of the five policymaking phases. Most papers addressed emergence, formulation, and funding phases. 
Table 3 Definitions of the five policymaking stages

\begin{tabular}{|c|c|c|}
\hline $\begin{array}{l}\text { Policymaking } \\
\text { stage }\end{array}$ & Definition & Matching indicator of government ownership \\
\hline Emergence & $\begin{array}{l}\text { The moment where a predictable or unpredictable } \\
\text { "policy window" is seized by decision makers for } \\
\text { initiating a strategy aiming at addressing an emerging } \\
\text { and sometimes burning issue [62]. Some authors refer } \\
\text { to it as the stage of "agenda-setting". }\end{array}$ & - Political will and leadership demonstrated at the highest level of government \\
\hline Formulation & The stage where the content of the policy is defined & $\begin{array}{l}\text { - Political will and leadership demonstrated at the highest level of government } \\
\text { - Effective engagement at technical and operational levels of government } \\
\text { - Capacity to act and coordinate actors within public agencies }\end{array}$ \\
\hline Funding & $\begin{array}{l}\text { The step where financial provisions are made available } \\
\text { to the implementing structure in charge of the policy } \\
\text { implementation. }\end{array}$ & $\begin{array}{l}\text { - Effective engagement at technical and operational levels of government } \\
\text { - Mobilization of national resources for contributing to finance the policy }\end{array}$ \\
\hline Implementation & $\begin{array}{l}\text { Ability of the State to lead and coordinate the } \\
\text { operationalization of the policy. }\end{array}$ & $\begin{array}{l}\text { - Effective engagement at technical and operational levels of government } \\
\text { - Capacity to act and coordinate actors within public agencies } \\
\text { - Mobilization of national resources for contributing to finance the policy }\end{array}$ \\
\hline Evaluation & Appreciating policy processes and outcomes [63]. & $\begin{array}{l}\text { - Effective engagement at technical and operational levels of government } \\
\text { - Capacity to act and coordinate actors within public agencies }\end{array}$ \\
\hline
\end{tabular}

\section{Government ownership at the emergence stage}

In general, ownership at the policy's emergence stage turned out to be very diverse, with evidence of leadership expressed at the highest level in some countries in the case of health insurance, recurring illustrations of political instrumentalization in view of upcoming elections in the case of user fee exemption, and some evidence of influence by donors in the case of PBF. In some instances, like in Tanzania and Burundi, authors reported that policy emergence came from both the government and the donors [116, 120]. However, because we cannot identify how the common decision was reached, we can hardly talk about full ownership of the emergence phase.

Our results showed that governments were instigating the emergence of health insurance and user fee exemption, and that other players (including donors) often

Table 4 List of exclusion criteria applied to select relevant papers

\begin{tabular}{|c|c|}
\hline \multicolumn{2}{|l|}{ Exclusion criteria } \\
\hline Content outside of scope $(N=18)$ & $\begin{array}{l}\text { Exclusive focus on policy outcomes } \\
\text { [64-75] Exclusive focus on vertical } \\
\text { programs dealing with HIV/AIDS, } \\
\text { malaria and tuberculosis [76-81] }\end{array}$ \\
\hline $\begin{array}{l}\text { Review of all health financing policy } \\
\text { options without specific content on } \\
\text { ownership }(N=6)\end{array}$ & {$[82-87]$} \\
\hline $\begin{array}{l}\text { Analysis of public's perceptions } \\
\text { about health financing policies } \\
(N=5)\end{array}$ & [88-92] \\
\hline $\begin{array}{l}\text { Review of options for fiscally } \\
\text { sustainable policies }(N=3)\end{array}$ & [93-95] \\
\hline $\begin{array}{l}\text { Lack of substantial content on } \\
\text { ownership }(N=6)\end{array}$ & [96-101] \\
\hline Full manuscript inaccessible $(N=1)$ & [102] \\
\hline $\begin{array}{l}\text { Short comments, not empirical } \\
\text { papers }(N=2)\end{array}$ & {$[103,104]$} \\
\hline
\end{tabular}

played a secondary role in SSA countries. In the case of user fee exemption, some authors noted that high-level politicians made the decision not for demonstrating leadership of the State in protecting its people but for "electoral benefits attached" to free health care [107]. Offering a package of free healthcare services represented a highly visible measure serving political campaigns. In addition, the decision to remove user fees was often controversial: in Burundi, Liberia and Uganda, the decision was made hastily and without any prior input from technical experts at the Ministry of Health [107]. Similar patterns characterized the emergence stage in Mali and Niger [112].

Emergence of health insurance followed a more gradual path, with a history of reforms on insurance in Ghana and Rwanda [105, 125]. In the case of Nigeria, high-level leadership came when a new minister of health "effectively managed stakeholders' interests and galvanized their support to advance the policy" [118]. In South Africa, the changing balance of power within the major political party, the African National Congress, represented a window of opportunity for undertaking the reform [116].

In one paper "political commitment" was perceived as the most important criterion influencing policymaking on user fee abolition or reduction; whereas "international pressure" was one of the least important criteria [126]. Nevertheless, in three papers there were indications that external players played a role in pushing for user fee exemption [107, 108, 112]. Donors in many West African countries influenced the policy idea, even if it happened within the government. In both Ghana and Senegal, there were reports of "donor pressure" for policymaking [107, 108]. In Burkina Faso and Niger, the World Bank put pressure on the governments for introducing user fee exemption [112]. In Mali, the need to be eligible to grants provided by the Global Fund prompted 


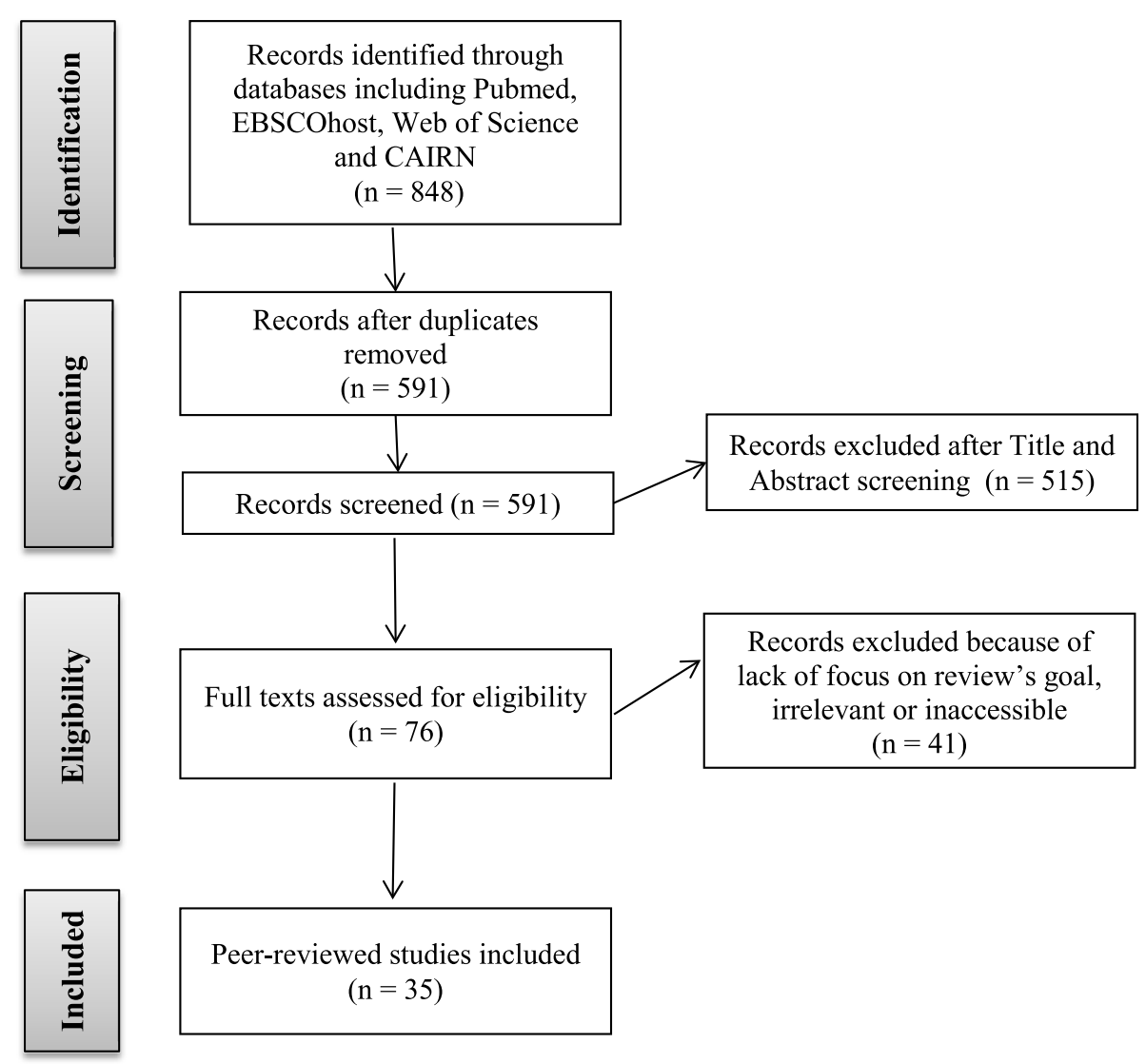

Fig. 1 "PRISMA" flow diagram. Legend: Adapted from [158]

the decision [112]. Interestingly, authors of another paper reported the generation and use by donors of a variety of evidence to "push" the user fee exemption policy in Uganda. This report suggests instrumentalization of knowledgebased resources for convincing governments [127].

As for performance-based financing (PBF), at the beginning neither Rwanda [123] nor Burundi [121, 124] were described as showing governmental ownership: international NGOs - latter with support from multilateral organizations (e.g., the World Bank) - implemented the policy through pilot projects. In Burundi, inspiration came from "the 1993 World Bank report 'Investing in Health', the agenda of the MDGs [...], and the PBF experience in neighboring Rwanda that was then described as 'encouraging"' [121]. Ye and colleagues also cited the potential of PBF to accelerate the achievement of MDGs as main driver for policy introduction [110]. In Rwanda, authors mentioned the 56th World Health Assembly [123]. In Benin, donors played an instrumental role in convincing the government of the value of PBF [128], and therefore in setting the policy window in favor of piloting and then scalingup PBF. In DRC, there was no information on the role(s) played by the State [129].
Government ownership at the policy formulation stage

Overall, government ownership at the policy formulation stage was mixed: there was a clear leadership at the highest level of power (at least for user fee exemption policies and health insurance in Nigeria and Ghana), but the State's ability to engage the technical and operational levels of government was ineffective; and the State's coordination efforts when designing the user fee exemption policy was limited.

High-level leadership appeared to have been substantial: ministries took leadership in developing scenarios for the introduction of insurance and user fee exemption schemes $[105,107,116,125]$. Concurrently, the influence of donors was considered limited. In Ghana, Rwanda, and South Africa, specific laws creating national health insurance schemes were promulgated in the 2000-decade. In Ghana, although there were reports of donors willing to influence the choice of insurance schemes and even "threaten[ing] to march the parliament", the government had the original bill passed [108]. User fee removal or reduction in Burkina Faso, Senegal and Uganda [107, 113, 117], as well as the PBF policy in Burundi [124] were integrated into countries' national strategic plans. Therefore, formulation appeared to be government-owned in these countries [130]. Yet, to be 
Table 5 Distribution of financing policies and countries addressed in each paper

\begin{tabular}{|c|c|c|c|c|}
\hline Article details & $\begin{array}{l}\text { User fee exemption } \\
\text { or reduction }\end{array}$ & $\begin{array}{l}\text { National } \\
\text { health } \\
\text { insurance }\end{array}$ & PBF & $\begin{array}{l}\text { PBF \& us } \\
\text { exemptic } \\
\text { reductior }\end{array}$ \\
\hline Agyepong et al. 2008 & & Ghana & & \\
\hline \multicolumn{5}{|l|}{ Atim 2011} \\
\hline Basaza et al. 2013 & & Uganda & & \\
\hline Chimhutu et al. 2014 & & & Tanzania & \\
\hline Chirwa et al. 2013 & Malawi & & & \\
\hline Falisse et al. 2012 & & & Burundi & \\
\hline Falisse et al. 2014 & & & & Burundi \\
\hline Fox et al. 2014 & & & & DRC \\
\hline Gilson et al. 2003 & & $\begin{array}{l}\text { South } \\
\text { Africa } \\
\text { Zambia }\end{array}$ & & \\
\hline Gilson et al. 2012 & & $\begin{array}{l}\text { South } \\
\text { Africa } \\
\text { Tanzania }\end{array}$ & & \\
\hline
\end{tabular}

Kajula et al. 2004

Uganda

Kirigia \& Diarra-Nama 2008

Countries of the WHO African region

Kusi-Ampofo et al. 2015

Ghana

Manitu et al. 2015

Masiye et al. 2010

Mbaye et al. 2013

McIntyre et al. 2013

\section{Zambia \\ Senegal \\ Malawi}

Meda et al. 2011

Meessen 2011

Burkina Faso

BurundiGhana

Liberia Senegal

Uganda

Nabyonga-Orem et al. 2014 Uganda

Nyandekwe et al. 2014

Olivier de Sardan et al. 2012 Burkina Faso

Mali

Niger

Onoka et al. 2014

Paul et al. 2014

Peerenboom et al. 2014

Ponsar et al. 2011

Ridde 2011

Ridde et al. 2012

Rusa et al. 2009

Seddoh \& Akor 2012

Thomas \& Gilson 2004

Torbica et al. 2014

Witter et al. 2013a

Witter et al. 2013b

Ye et al. 2014

Total

Mali

Mali
Benin Burkina Faso

Niger Togo Senegal

Nigeria

Tanzania

DRC

Burkina Faso

Nigeria

Benin

Burundi

Burkina Faso
Africa (all countries)
All UHC financing policies 
Table 6 Information about publication period, types of papers, and study design

\begin{tabular}{ll}
\hline Publication period & \\
Papers published between 2011 and 2015 & $N=28$ \\
$\begin{array}{l}\text { Papers published between } 2006 \text { and } 2010 \\
\text { Papers published between } 2001 \text { and } 2005\end{array}$ & $N=4$ \\
$\begin{array}{l}\text { Types of papers } \\
\text { Original research articles }\end{array}$ & $N=32$ \\
$\begin{array}{l}\text { Reviews } \\
\text { Conference report }\end{array}$ & $N=2$ \\
Study design & $N=1$ \\
Qualitative methods & \\
Quantitative methods & $N=22$ \\
Mixed methods & $N=10$ \\
\hline
\end{tabular}

able to say that there was ownership at this stage, one also needs to look at the effective engagement of technical and operational levels of government. High-level leadership also needs to be assessed at the policy formulation phase.

Many authors described the technical design of user fee exemption policies as chaotic [107, 112, 113, 126, 131]. The unexpectedness of the decision-making hindered technical inputs from national experts for the development of well-planned policies and their related procedures and implementing rules $[107,112]$. The technical level of government did not own the formulation process. As a result, the ability of the State to coordinate actors within public agencies when designing the user fee exemption policy was also limited.

In South Africa and Uganda, ownership of the health insurance policymaking was somehow undermined, but not because of external influence. Other actors involved played a crucial role in negotiating the content of insurance schemes, such as political factions and, more importantly, the private sector $[115,116]$. Finally, in Tanzania, politicians played a minor role. Policymaking was mainly the product of top management's power in the largest mandatory formal sector scheme - the National Health Insurance Fund, a technical agency [116].

\section{Government ownership at the funding stage}

After demonstrating high leadership, governments are expected to secure domestic funding for implementation. Findings were also mixed at the funding stage. While there was evidence of government ownership for health insurance and to a lesser level, user fee exemption, on the contrary, funding for PBF schemes did not appear to come from the governments.

First, authors of most papers highlighted the high dependence of SSA countries covered in this review on external aid (except South Africa, and to a lesser extent, Nigeria) [27]. Some results suggested that this characteristic was conducive of a low ownership of the policymaking process: Tanzania's and Zambia's dependence on donors gave influence to the latter in debates over health policies whereas donors' role was irrelevant in South Africa [119, 131]. However this pattern did not necessarily reflect other aid-dependent countries. In Ghana, external actors played a minimal role, mainly through provision of support to mutual health organization and development of training manuals [105]. The implementation of the nation-scale reforms was the opportunity for the State to mobilize more domestic funding, thereby demonstrating high ownership. In Rwanda, domestic resources were increased as a way to ensure the insurance scheme's financial sustainability [125].

As far as user fee policies are concerned, the donor dependence thesis was irrelevant as well because most countries introducing user fee exemption largely (Burundi, Ghana, Niger, Uganda) or even exclusively (Burkina Faso) funded the reform implementation through their national budgets [107, 109, 112, 126]. Ridde explained that Burkina Faso demonstrated a particularly high level of commitment by funding through its national budget subsidies covering direct costs [113]. Meessen and colleagues emphasized the use of the Highly Indebted Poor Countries (HIPC) Initiative by governments as "a key instrument to finance the reform" [107]. In a review, despite high levels of external aid in West Africa [107], selected policymakers rated "financial sustainability" as "quite important", yet less critical than other criteria such as "political leadership". "Donor money" was the "least important" of all criteria [126]. The case of Ghana was peculiar: the British government provided funding for covering the costs of free deliveries during the first year of implementation before Ghana's government could take over with domestic funding [109]. However, the situation was often more complex than it looked: policymakers found themselves calling for international donors or NGOs to match the limited domestic funding $[107,112]$.

In the case of PBF, we found that funding widely came from donors. In Benin and Tanzania, pilot PBF schemes, purchasing of services was entirely covered by donors [128, 132]. In Burundi, the State contributed to half (52\%) of the funding for the nation-wide PBF scheme [120]. In Rwanda, we could not find any figure on funding sources in Rusa et al. In a paper about the forthcoming introduction of PBF in Ghana, Burkina Faso, and Tanzania, interviewees, conscious of the policy's dependence upon donor funding, supported local resources mobilization [110]. They were in favor of finding alternative ways towards creating "a sustainable incentive scheme that could be financed at the local level without external partner support" [110].

\section{Government ownership at the implementation stage}

Overall, the governments' capacity to effectively engage with and coordinate actors within public agencies to 
Table 7 Policymaking stages addressed in selected papers

\begin{tabular}{|c|c|c|c|c|c|}
\hline Article details & Emergence & Formulation & Funding & Implementation & Evaluation \\
\hline Agyepong et al. 2008 & & $x$ & $x$ & $x$ & \\
\hline Atim 2011 & & $x$ & $x$ & & \\
\hline Basaza et al. 2013 & $x$ & $x$ & $x$ & $x$ & \\
\hline Chimhutu et al. 2014 & $x$ & & $x$ & & \\
\hline Chirwa et al. 2013 & $x$ & $x$ & $x$ & $x$ & $x$ \\
\hline Falisse et al. 2012 & $x$ & $x$ & $x$ & $x$ & $x$ \\
\hline Falisse et al. 2014 & $x$ & $x$ & & & \\
\hline Fox et al. 2014 & $x$ & $x$ & $x$ & $x$ & \\
\hline Gilson et al. 2003 & $x$ & $x$ & $x$ & $x$ & \\
\hline Gilson et al. 2012 & $x$ & $x$ & $x$ & & \\
\hline Kajula et al. 2004 & $x$ & $x$ & $x$ & $x$ & \\
\hline Kirigia \& Diarra-Nama 2008 & & & $x$ & & \\
\hline Kusi-Ampofo et al. 2015 & $x$ & & & & \\
\hline Manitu et al. 2015 & $x$ & & $x$ & $x$ & $x$ \\
\hline Masiye et al. 2010 & $x$ & $x$ & $x$ & $x$ & \\
\hline Mbaye et al. 2013 & $x$ & $x$ & $x$ & & \\
\hline Mclntyre et al. 2013 & $x$ & $x$ & $x$ & $x$ & \\
\hline Meda et al. 2011 & & & $x$ & $x$ & $x$ \\
\hline Meessen 2011 & $x$ & $x$ & $x$ & $x$ & $x$ \\
\hline Nabyonga-Orem et al. 2014 & $x$ & & $x$ & & \\
\hline Nyandekwe et al. 2014 & $x$ & $x$ & $x$ & $x$ & \\
\hline Olivier de Sardan et al. 2012 & $x$ & $x$ & $x$ & $x$ & \\
\hline Onoka et al. 2014 & $x$ & $x$ & & $x$ & \\
\hline Paul et al. 2014 & $x$ & $x$ & $x$ & $x$ & \\
\hline Peerenboom et al. 2014 & & $x$ & $x$ & $x$ & $x$ \\
\hline Ponsar et al. 2011 & & $x$ & $x$ & $x$ & \\
\hline Ridde 2011 & $x$ & $x$ & $x$ & $x$ & $x$ \\
\hline Ridde et al. 2012 & $x$ & $x$ & $x$ & & \\
\hline Rusa et al. 2009 & $x$ & $x$ & & $x$ & $x$ \\
\hline Seddoh et Akor 2012 & $x$ & $x$ & & & \\
\hline Thomas \& Gilson 2004 & $x$ & $x$ & & & \\
\hline Torbica et al. 2014 & $x$ & $x$ & $x$ & $x$ & \\
\hline Witter et al. 2013a & $x$ & $x$ & $x$ & & \\
\hline Witter et al. 2013b & $x$ & $x$ & $x$ & $x$ & \\
\hline Ye et al. 2014 & $x$ & & $x$ & & \\
\hline Total & 29 & 28 & 29 & 22 & 8 \\
\hline
\end{tabular}

implement these policies was considered limited. User fee exemption policies were implemented with a substantial degree of "improvisation" that illustrated substantial planning deficiencies from the public authorities [112]. In West Africa and Malawi, barriers to the effective implementation were numerous: unpreparedness at the technical, financial and communication levels [112, 131, 133]; incapacity of the health system to sufficiently respond to increasing demand induced by user fee removal; etc. In
Burkina Faso, Mali, and Niger these issues did not however impede policy, which was operationalized by national technicians "without any particular form of external assistance" [111]. The case of Niger was symptomatic of insufficient financial planning. The president claimed a "sovereign" decision based on national funding, yet according to authors the State proved unable to meet its financial commitments [112]. Other authors reported that in Mali, a NGO played an instrumental role in operationalizing 
the user fee exemption for malaria treatment [122]. Malawi for its part reportedly failed to plan and provide adequate funding to cover the cost of the "free" services [131]. In this case, the ability to secure funding at the implementation stage was lacking. Zambia was better equipped for implementing user fee exemption: funds were planned ahead of time to ensure drug provision [134].

Interestingly, the Ugandan government chose to "diffuse ownership of the reforms to the local governments" [117]. However this strategy reportedly "undermined the ability of the national reform group to effectively advocate for and implement the reforms" [117]. Decentralization was also extensively relied upon to implement health insurance in Nigeria and led to important problems. The ability of the central government to transfer leadership to decentralized governments therefore proved insufficient [118, 131]. In Tanzania, communication about the insurance policy was inadequate [130]. These examples might indicate that in Nigeria, Tanzania, and Uganda, the lack of involvement of technical and operational staff was impeding ownership by implementers. On the contrary, in Ghana, the national insurance policy was implemented without substantial issues, and with very limited intervention from external actors [105].

As per the content of the reviewed body of literature, government ownership in PBF policy operationalization appeared to be limited. In Manitu et al.'s paper, some interviewees expressed concerns that implementing PBF would entail the creation of parallel structures, which in turn would lead to ownership issues [135]. In Burundi, until 2014, implementation of PBF schemes lied in the hands of donors and international NGOs [120, 124]. Transfer of "management and stewardship" was supposed to occur between donors and governments, which according to some authors, officially happened [124]. In Benin, the political discourse appeared to be highly supportive of PBF [128] but debates over national scale-up are still ongoing.

Many articles tackled the need to strengthen the State's ability to coordinate efforts from all stakeholders involved in policy implementation. For example, authors advocated for more collaboration between political leaders and technocrats in undertaking policies aiming at UHC $[112,130]$. Sub-Saharan governments' coordination capacity was seldom assessed in terms of managing external actors. At the time of publishing, coordination mechanisms were not in place in all countries, and when they were, the extent of their coverage was not always optimal [107].

\section{Government ownership at the evaluation stage}

Ownership of evaluating decision-making on policies aiming at UHC appeared to be fairly limited in the majority of papers, but in the case of Burkina Faso we noted the ability of district health teams to come up with innovative ways to report results.

In the case of PBF, donors were portrayed as both the main instigators and the co-implementers (with governments) of the policy. They strongly engaged in the evaluation process as the continuation of their missions. This was true for Burundi and Rwanda in particular [120, 123, 124]: the authors of these papers mentioned the government and the financial and technical partners as undertaking together the evaluation phase and drawing recommendations and conclusions from it, without distinguishing the roles played by each of them. The degree of government ownership was therefore unclear at this stage. In Manitu et al., some interviewees criticized the fact that experts documenting several PBF experiences were the same that promoted the strategy. Authors recommended that the evaluation be carried out by neutral teams [135].

As for user fee exemption, authors described weak evaluation procedures in five countries [107], and a lack of any "basic system to monitor progress". Government ownership was hampered here not because of some external influence, but because of internal weaknesses. On the contrary, Meda et al. showed that district teams played a leading role in communicating about both the processes and outcomes of the multiple policies that were being implemented [111].

\section{General results on government ownership}

The preliminary identification of ownership indicators and their linkage to policymaking stages proved to be useful strategies to analyze government ownership of policymaking aiming at UHC. The majority of the selected papers (26/35) presented mixed results in terms of government ownership. In other words, in most papers there was evidence of ownership at one or more stages of the policy implementation process but not all (see Additional File 2 for details).

\section{Discussion}

\section{A critical look into our main results}

This scoping review of the peer-reviewed literature demonstrated mixed results about government ownership of health financing policies aiming at UHC. Authors of only five papers provided evidence of ownership at all reviewed policymaking stages.

In the case of insurance and user fee exemption, when emergence and formulation phases were reportedly government-owned, it was due to political leadership expressed at the highest level of governments. These decisions were often highly personalized in order to ensure political election or re-election, and entailed many technical difficulties for most SSA countries. In addition, when results pointed to a lack of governmental 
ownership, donors were not necessarily responsible for this situation. Also, donors' intervention was not necessarily undermining ownership: there were multiple reports of government ownership and donors' influence successfully coexisting.

Our analysis of the PBF policy was more straightforward: as per our review, donors' involvement at all policymaking stages (as reported in the selected papers) led to limited government ownership. Indeed, there was limited evidence that PBF policymaking processes were government-owned. In the case of PBF as a national policy, as in Burundi and Rwanda, selected papers did not provide much information about government ownership - but other sources may indicate greater ownership for these two countries. In most SSA countries where it is still a pilot policy, apart from political support, the ability of governments to plan for future institutionalization and funding came forward neither in this review, nor in recent publications [136, 137]. Funding of PBF remains largely ensured by donors [138].

Based on these main results, we identify three areas that need to be discussed. First, the observed differences in terms of ownership and donors' influence between the policies ought to be explained. Second, reports of a lack of external influence on user fee exemption and, to a lesser extent, health insurance, were often hiding contrasting realities. Third, there is a need to further explain the idea that donors' influence and government ownership may successfully coexist.

\section{Attempting to explain differences across the three policies}

Why were there differences between health insurance and user fee exemption on one hand, and PBF on the other hand? First, the level of involvement of donors may explain this discrepancy. While there was an explicit push by donors to undertake two health financing reforms in the 2000s (health insurance and user fee exemption), at the emergence stage, they were less proactive at the funding stage: they hardly provided any specific funding for implementation. The supply-side nature of the PBF policy possibly required greater financial mobilization so as to yield faster results in health facilities: PBF pilot schemes were fully funded by donors. On the contrary, health insurance and user fee exemption are demand-side policies and therefore as such, did not necessarily need high disbursements. The low level of external funding for health insurance could be explained by the structure of insurance itself, which relies on both public and private contributions that are later pooled for members' benefit.

In the case of PBF, each stage of the policymaking process appeared to be substantially influenced by external actors: PBF pilot programs were thoroughly promoted, designed, funded, implemented, and evaluated by donors and NGOs. The high influence by external actors might be explained by the implications of PBF itself, which purportedly entails better monitoring of funded activities - thereby allowing the emergence in SSA countries of systems that would better track aid funding in general [15]. It is likely that donors perceive PBF as fulfilling their goals in a more efficient way than other policies aiming at UHC [137-140].

Second, it may be that, as an analysis of sustainable development policies in Madagascar also highlighted [139], when donors are simultaneously involved (as in the case of PBF) in policy's emergence, funding, implementation (through technical support provision to the government), and evaluation stages, government ownership of the policymaking process is likely to be undermined [140]. Concurrently, Sjöstedt argued that there are "inherent tensions" between the principles of government ownership and donors voicing their interests and political priorities of their own governments together with "continuously measuring and reporting results" [33].

\section{A superficially high degree of government ownership?}

Authors described emergence and formulation as government-owned, based on political leadership expressed at the highest level. However, in the case of user fee exemption policies, there were multiple reports of highly personalized decisions made to increase the popularity of their promoters, not to improve people's access to care. The subsequent technical difficulties demonstrated that the policy process was not was not fully owned. Moreover, the factors influenced decision-making: some authors acknowledged that SSA governments might have favored the adoption of this policy because "it complies with the health policy vision of the country and of the donors" [107]. The balance of power between national and international actors remains to be analyzed more in-depth.

We did find an example where the results on donors' influence was presented as low while in fact it was fairly high: in Uganda, the $\mathrm{P} 4 \mathrm{H}$ consortium was not described as a donor (despite being composed of various multilateral and bilateral agencies) but had a substantial influence as a major advocate and financer of the national health insurance scheme [115]. We also found that the analyses provided by the authors on funding for user fee exemption in SSA countries might have missed the broader picture. Indeed, authors reported that countries provided funding to implement their policies primarily from their own budget $[107,112,126]$. However, when searching for the specific national fund that was used, we found the name of the "Highly Indebted Poor Countries Initiative (HIPC)", which was reportedly used in four countries [107]. The HIPC used to be an instrument available to the State's discretion (albeit for social purposes) that is entirely funded by donors [141]. Therefore, even though the decision to use these funds did 
come from SSA countries' governments [142], funding could not be labeled as coming from national sources. In fact, this paper showed that the use of the HIPC fund generated a "wait-and-see attitude" on the Ghanaian government's side in terms of domestic resource mobilization [142]. By taping into this kind of fund, one risks creating more donor dependency instead of more ownership.

\section{Successful coexistence of donors' influence and government ownership}

Donors' intervention was not necessarily undermining ownership. Indeed, in this review, there were multiple reports of donors and governments working hand in hand towards agenda-setting and formulation. The healthcare user fee exemption policy was an interesting case: the policy apparently emerged through a shared vision between external and internal actors in most countries, and it was formulated through strong political will and leadership of the governments [107, 112, 117].

Consistent with this finding, other literature pinpoint that while we cannot speak of "pure imposition" by external actors anymore $[143,144]$, the transmission to the national level of policies originating from external actors does still happen in the form of a "collaborative interaction" between them and domestic actors $[145,146]$. Some authors argue that SSA countries' elites actively participate in this collaborative policy transfer [147].

\section{Strengths and limits of the review}

This paper represents the first attempt at analyzing the critical features of government ownership in relation to health financing policies aiming at UHC, by looking at each step of the policymaking process in a systematic fashion. This paper addresses a highly relevant topic for scholars and policymakers with interests in the governance of global-national interface, health financing, and universal health coverage. In addition, this review interestingly reports on differentiated findings and unexpected results: these may open new avenues for research

Our review has some limitations. First, as indicated in the introduction, we chose to limit the investigation to the geographic area of Sub-Saharan Africa. While we believe that this restriction has no impact on the richness of data on user fee exemption and health insurance, we are lacking the experience of other results-based financing policies (including conditional cash transfers and output-based aid) outside of our focus continent.

Second, as also noted in the introduction, we were not able to not look at policies aiming at UHC in its multidimensional meaning, given that global attention and efforts have focused on the financial dimension of UHC over the past decade.
Third, results-based financing policies, like PBF, still consist of pilot programs in most SSA countries. We consider that the making of public policies "results partly from a sustainability process, notably through actions implemented as pilot project" [148]. In our review, we described and analyzed PBF as a public policy since governments of these countries have participated in their implementation (by providing the available human and material resources) and demonstrated political will for making them countrywide public policies. Readers should also be aware that PBF is still relatively new in most SSA countries: our results may not represent the long-term picture.

Fourth, we decided not to include grey literature or primary policy documents. Indeed, in spite of their relevance, adding this type of non peer-reviewed literature about government ownership in all SSA countries could not have been done in the same transparent and traceable manner.

\section{Implications for future research}

Future research in the area of government ownership and health financing in developing countries should analyze the historical contexts behind the imbalance of power between the different actors during policy negotiations. Researchers should also investigate the power of national actors themselves, such as exploring how some national actors become themselves policy champions, manage to convince other key actors, and thereby influence formulation.

\section{Unpacking the complexity of donors' influence}

Traditionally, external donors have had a major influence on decision-making. De Renzio et al. argue that beyond aid dependency, the history of engagement with donors was instrumental in shaping donors' authority [47]: the debt and balance of payments crises of the 1970s-1980s prompted many SSA countries to seek financial help from the IFIs. In these countries, "donors soon expanded their influence from macroeconomic policies [...], to the process of policymaking itself by the early 2000s" [47]. Such a situation created the conditions of a loss of ownership. However, scholars in health financing policymaking appear to have overlooked these historical accounts. Future research on UHC policymaking should aim at filling this gap [60].

Furthermore, donors did not always show a united influence. There was evidence that donors negotiated among themselves to influence the course of policy emergence and formulation. Tanzania's case was emblematic: in two instances, two groups of donors confronted each other on the preferred financial arrangement (health insurance vs. tax funding) and on the introduction of PBF $[116,140]$. Amidst these negotiations, the Tanzanian government was unable to take on the leading role it was supposed to play. In Benin, tensions between the Belgian and World Bank PBF schemes also appeared to have emerged [128]. In 
light of these findings, future investigations need to explore how donors coordinate policies aiming at UHC.

\section{Need for further investigation of the roles played by national actors}

Beyond looking at donors' influence on emergence, it is important to analyze the path of national actors identifying with a given policy and taking the lead in pushing it forward to secure policy formulation [105, 113, 118, 126, 149]. However, we could find little information about the ways these national actors were organized and the extent to which they identified with a policy that emerged externally. A recent paper identified the lack of "national policy entrepreneurs" as the main reason for the "failed" emergence of PBF in Chad [150]. Analyzing the paths of national "policy champions" is an avenue for future research.

Besides political elites, other factors may influence policymaking processes. For instance, a context of chronic political instability can undermine the implementation and financial sustainability of policies. None of the papers addressed this particular influence. The role played by other non-state actors and scientific evidence was scarcely tackled in the selected papers. We showed that other non-state actors such as NGOs and countries' private sector have an impact on governments' decisions, as this was the case in Mali (on user fee exemption), South Africa, and Uganda (on health insurance); yet the action and interests of such non-state actors (whether they are domestic or foreign), increasingly financially supported by bilateral donors [151, 152], may conflict with those of the governments and undermine the position of the State [153, 154]. One paper also highlighted the influence on policymaking of scientific and experts' evidence produced and disseminated by donors [127]: this finding concurs with other works at both national and global scales [155-157]. Future research should address the influence of these non-state actors as well as the category of "non-human" drivers of policymaking.

\section{Implications for practice: the way towards effective government ownership of policies aiming at UHC}

Based on this review, it is possible to formulate a few recommendations. First, we advise that pilot schemes be carefully planned by clarifying the roles played by each category of actors, notably by distinguishing political advocacy, funding, technical support for policy implementation, and evaluation. We suggest using donor funding for i) supporting the development of national UHC policies and infrastructure, ii) building and strengthening long-term State capacities in coordinating the different actors involved at any stage of the policymaking, and iii) providing ideas for domestic funding mobilization (e.g., increased taxation of international companies established in the country).

\section{Additional file}

Additional file 1: Search strategy. (DOCX 13 kb)

Additional file 2: Main findings from the review about government ownership. Legend: Red color indicates lack of evidence of government ownership (lack evidence of ownership indicators based on selected papers' findings); yellow color indicates mixed evidence of government ownership (mixed evidence); green color indicates evidence of government ownership (evidence). (DOCX 160 kb)

\section{Abbreviations}

CCTs: Conditional cash transfers; IFIs: International Financial Institutions; NGOs: Non-governmental organizations; PBF: Performance-based financing; RBF: Results-based financing; UHC: Universal health coverage; WHO: World Health Organization

\section{Acknowledgments}

We would like to thank Professor Mira Johri and Professor Vinh-Kim Nguyen for providing suggestions in the first iteration of this paper. We would also like to thank Heather Hickey for proofreading the article as well as four anonymous reviewers for their useful comments.

\section{Funding}

LG would like to thank the REALISME Research Chair of the Canadian Institutes Health Research (CPP 137901) and the School of Public Health of the University of Montreal for financial support during the year throughout which this research was undertaken. Currently, LG receives a PhD scholarship from Fonds de Recherche du Québec - Société et Culture (FRQSC). VR holds a CIHR-funded Research Chair in Applied Public Health (CPP 137901).

\section{Availability of data and materials}

All data supporting our findings is contained in the manuscript and there are no restrictions to data sources. Since this study is a review, data accessed and reviewed is also available to the public on the various journal and official website sources, all cited and detailed in the references section of this manuscript.

\section{Authors' contributions}

LG conceived the scoping review, extracted and analyzed data, and drafted the initial version of this manuscript. VR revised each version of the manuscript and provided substantial inputs. Both authors approved the final manuscript.

\section{Competing interests}

VR has served as a consultant on the issue of user-fee abolition to nongovernmental organizations. VR is a co-researcher on the baseline and endline study of the impact evaluation of PBF in Burkina Faso but has received no salary from the funder (World Bank) for this activity. The authors have no conflicts of interests regarding the publication of this paper.

\section{Consent for publication}

Not applicable.

\section{Ethics approval and consent to participate} Not applicable.

\section{Author details \\ ${ }^{1}$ Department of social and preventive medicine, School of Public Health, Université de Montréal, Montréal, Québec, Canada. ²Public Health Research Institute (IRSPUM), Université de Montréal, Montréal, Québec, Canada. \\ ${ }^{3}$ Centre d'Etudes en Sciences Sociales sur les Mondes Africains, Américains et Asiatiques, Université Paris Diderot-Paris VII, Sorbonne Paris Cité, Paris, France.}

Received: 22 August 2016 Accepted: 8 June 2017

Published online: 08 August 2017

\section{References}

1. World Health Organization. World health report 2010 [Internet]. WHO. [cited 2015 Jan 20]. Available from: http://www.who.int/healthsystems/topics/ financing/healthreport/whr_background/en/ 
2. Kruk ME. Universal health coverage: a policy whose time has come. BMJ. 2013;347:f6360.

3. Ooms G, Brolan C, Eggermont N, Eide A, Flores W, Forman L, et al. Universal health coverage anchored in the right to health. Bull World Health Organ. 2013;91:2-2A.

4. Touraine $M$, Gröhe $H$, Coffie RG, Sathasivam S, Juan M, Louardi EH, et al. Universal health coverage and the post-2015 agenda. Lancet. 2014;384:1161-2.

5. Universal health coverage post-2015: putting people first. Lancet. 2014;384:2083.

6. World Health Organization. Universal health coverage (UHC) factsheet [Internet]. WHO. [cited 2015 Jan 20]. Available from: http://www.who.int/ mediacentre/factsheets/fs395/en/

7. The United Nations Department of Economic and Social Affairs. Transforming our world: the 2030 Agenda for Sustainable Development : Sustainable Development Knowledge Platform [Internet]. 2016 [cited 2017 May 18]. Available from: https://sustainabledevelopment.un.org/post2015/ transformingourworld

8. Evans DB, Marten R, Etienne C. Universal health coverage is a development issue. Lancet. 2012;380:864-5.

9. Lagomarsino G. An Evolving Global Movement Toward UHC: From Financing to Primary Care-focused Delivery [Internet]. PHCPI. 2015 [cited 2016 Oct 14]. Available from: http://phcperformanceinitiative.org/blog/2015/ 12/17/evolving-global-movement-toward-uhc-financing-primary-carefocused-delivery

10. WHO/World Bank Ministerial-level Meeting on Universal Health Coverage. Report on the ministerial level roundtable on Universal Health Coverage [Internet]. Geneva: WHO/World Bank; 2013. Available from: http://www.who. int/health_financing/ministerial_meeting_report20130328.pdf

11. Waelkens M-P, Criel B. Les mutuelles de santé en Afrique sub-saharienne: État des lieux et réflexions sur un agenda de recherche [Internet]. World Bank; 2004. [cited 2016 oct 14] Available from: http://siteresources. worldbank.org/HEALTHNUTRITIONANDPOPULATION/Resources/2816271095698140167/Waelkens-LesMutuelles-whole.pdf.

12. Ridde $V$, Blanchet $K$. Débats et défis autour de la gratuité des soins en Afrique: "retour vers le futur"? Cah Détudes Rech Francoph. 2009;19:101-6.

13. Fritsche GB, Soeters R, Meessen B, Ndizeye C, Bredenkamp C, van Heteren G. PBF Toolkit [Internet]. Washington: World Bank Group; 2014. [cited 2015 Jan 17]. Available from: http://elibrary.worldbank.org/doi/pdf/10.1596/978-14648-0128-0.

14. Barnes A, Garrett Wallace B, Harman S. Locating Health Diplomacy through African Negotiations on Performance-based funding in global health. J Health Dipl [Internet]. 2015; [cited 2016 Jan 10];1. Available from: https:// www.academia.edu/14917159/Locating_Health_Diplomacy_through_ African_Negotiations_on_Performance-based_funding_in_global_health.

15. Kutzin J, Yip W, Cashin C. Alternative financing strategies for universal health coverage. Handb Glob Health Econ Public Policy [Internet]. 2016; [cited 2017 May 20];1. Available from: https://books.google.fr/books?hl=fr\&lr=\&id= I3rQDAAAQBAJ\&oi=fnd\&pg=PT293\&dq=Alternative+financing+strategies +for+universal+health+coverage\&ots=4ZQHpSCMfw\&sig= v6nN73SyFYh7bQ2wn1DZnm6P010.

16. Soucat A, Dale E, Mathauer I, Kutzin J. Pay-for-Performance Debate: Not Seeing the Forest for the Trees. Health Syst. Reform. 2017;3:74-9.

17. Nauleau M, Destremau B, Lautier B. « En chemin vers la couverture sanitaire universelle ». Rev. Tiers Monde. 2013;215:129-48.

18. Lagomarsino G, Garabrant A, Adyas A, Muga R, Otoo N. Moving towards universal health coverage: health insurance reforms in nine developing countries in Africa and Asia. Lancet. 2012;380:933-43.

19. Mullen GED, Giersing BK, Ajose-Popoola O, Davis HL, Kothe C, Zhou H, et al. Enhancement of functional antibody responses to AMA1-C1/Alhydrogel ${ }^{\circledR}$, a Plasmodium falciparum malaria vaccine, with $\mathrm{CpG}$ oligodeoxynucleotide. Vaccine. 2006;24:2497-505.

20. de Noronha JC. Universal health coverage: how to mix concepts, confuse objectives, and abandon principles. Cad Saúde Pública. 2013;29:847-9.

21. Saksena P, Hsu J, Evans DB. Financial risk protection and universal health coverage: evidence and measurement challenges. PLoS Med. 2014;11:e1001701.

22. Macmillan Dictionary. Ownership definition and synonyms [Internet]. MacMillan Dict. @ Macmillan Publishers Limited 2009-2016; [cited 2016 Oct 16]. Available from: http://www.macmillandictionary.com/dictionary/british/ownership.

23. Hunt MR, Gogognon P, Ridde V. Ethical considerations related to participation and partnership: an investigation of stakeholders' perceptions of an action-research project on user fee removal for the poorest in Burkina Faso. Bmc Med Ethics. 2014;15:13.
24. Adams V, Burke NJ, Whitmarsh I. Slow research: thoughts for a movement in global health. Med Anthropol. 2014;33:179-97.

25. Ottersen OP, Dasgupta J, Blouin C, Buss P, Chongsuvivatwong V, Frenk J, et al. The political origins of health inequity: prospects for change. Lancet. 2014;383:630-67.

26. Buse K, Harmer AM. Seven habits of highly effective global publicprivate health partnerships: practice and potential. Soc Sci Med. 1982. 2007;64:259-271.

27. De Ceukelaire W, Botenga MJ. On global health: stick to sovereignty. Lancet. 2014;383:951-2.

28. Kelly MG. International biopolitics: Foucault, globalisation and imperialism. Theoria. 2010;57:1-26.

29. Kirigia JM, Diarra-Nama AJ. Can countries of the WHO African Region wean themselves off donor funding for health? Bull World Health Organ. 2008;86:889-92.

30. Kickbusch I, Marianna Cassar Szabo M. A new governance space for health. Glob. Health Action [Internet]. 2014 [cited 2015 Feb 20];7. Available from: http://www.tandfonline.com/doi/full/10.3402/gha.v7.23507.

31. Lee K. Health Impacts of Globalization: Towards Global Governance. Basingstoke: Palgrave Macmillan; 2003.

32. Møgedal S. Development and Health: Current Challenges in Development Assistance. Forum Dev Stud. 1993;20:5-19.

33. Sjöstedt M. Aid Effectiveness and the Paris Declaration: A Mismatch Between Ownership and Results-Based Management? Public Adm Dev. 2013;33:143-55.

34. Bergamaschi I. «Appropriation » et « lutte contre la pauvreté » au Mali. Rev Tiers Monde. 2011; $n^{\circ} 205: 135-50$.

35. Tirole J. Financial crises, liquidity, and the international monetary system. Princeton: Princeton University Press; 2002.

36. Esser DE. Elusive accountabilities in the HIV scale-up: "Ownership" as a functional tautology. Glob. Public Health. 2014;9:43-56.

37. Helleiner GK, Killick T, Lipumba N, Ndulu BJ, Svendsen KE. Report of the group of independent advisers on development cooperation issues between Tanzania and its aid donors. Copenhagen: Royal Danish Ministry of Foreign Affairs; 1995.

38. Woll B. The ownership paradox: the politics of development cooperation with Bolivia and Ghana [Internet] [phd]. The London School of Economics and Political Science (LSE); 2006 [cited 2015 Nov 11]. Available from: http://etheses.lse.ac.uk/856/.

39. Organisation for Economic Co-operation and Development. The Paris declaration on aid effectiveness. [Internet] Organisation for Economic Co-operation and Development; 2005 [cited 2015 Nov 11]. Available from: http://www.oecd.org/dac/effectiveness/34428351.pdf.

40. Saiget M. Chapitre 5. UNIFEM/ONU Femmes et les bonnes pratiques de la participation. Relat Int. 2015:113-29.

41. Buffardi AL. Configuring "country ownership": patterns of donor-recipient relations. Dev Pract. 2013;23:977-90.

42. Buiter WH. "Country ownership": a term whose time has gone. Dev Pract. 2007;17:647-52.

43. Solter $\mathrm{S}$, Solter $\mathrm{C}$. Providing technical assistance to ministries of health: lessons learned over 30 years. Glob Health Sci Pract. 2013;1:302-7.

44. West GR, Clapp SP, Averill EMD, Cates W. Defining and assessing evidence for the effectiveness of technical assistance in furthering global health. Glob Public Health. 2012;7:915-30.

45. Bidaurratzaga-Aurre $E_{1}$ Colom-Jaén A. HIV/AIDS policies in Mozambique and the new aid architecture: successes, shortcomings and the way forward. J Mod Afr Stud. 2012;50:225-52.

46. Goldberg J, Bryant M. Country ownership and capacity building: the next buzzwords in health systems strengthening or a truly new approach to development? BMC Public Health. 2012;12:531.

47. De Renzio P, Whitfield L, Bergamaschi I. Policy Brief: Reforming Foreign Aid Practices (2008) [Internet]. Global Economic Governance; 2008. Available from: http://www.globaleconomicgovernance.org/policy-brief-reformingforeign-aid-practices-2008.

48. Hirsch JS, Giang LM, Parker RG, Duong LB. Caught in the Middle: The Contested Politics of HIV/AIDS and Health Policy in Vietnam. J Health Polit Policy Law. 2015;40:13-40.

49. Hyden G. After the Paris Declaration: Taking on the Issue of Power. Dev Policy Rev. 2008;26:259-74.

50. Pallas SW, Nonvignon J, Aikins M, Ruger JP. Responses to donor proliferation in Ghana's health sector: a qualitative case study. Bull World Health Organ. 2015;93:11-8. 
51. Ghebreyesus TA. Achieving the health MDGs: country ownership in four steps. Lancet. 2010;376:1127-8.

52. Sengupta A. Universal health coverage: Beyond rhetoric [Internet]. Municipal Services Project; 2013. Report No: 20. Available from: http///mww. municipalservicesproject.org/publication/universal-health-coverage-beyondrhetoric.

53. Stuckler D, Feigl A, Basu S, McKee M. The political economy of universal health coverage. Background paper for the global symposium on health systems research [Internet]. 2010 [cited 2015 Feb 18]. Available from: http://researchonline.lshtm.ac.uk/2157/.

54. Mays N, Roberts E, Popay J. Synthesising research evidence. In: Fulop N, editor. Studying the Organisation and Delivery of Health Services: Research Methods. London: Routledge; 2001. p. 188-220.

55. Arksey H, O'Malley L. Scoping studies: towards a methodological framework. Int J Soc Res Methodol. 2005:8:19-32.

56. Levac D, Colquhoun H, O'Brien KK. Scoping studies: advancing the methodology. Implement Sci. 2010;5:1.

57. Pluye P, Hong QN. Combining the Power of Stories and the Power of Numbers: Mixed Methods Research and Mixed Studies Reviews. Annu Rev Public Health. 2014;35:29-45.

58. Rocher G. Les réformes: une perspective sociologique. Montréal: Centre de recherche en droit public, Université de Montréal; 2004.

59. Howlett M, Ramesh M, Perl A. Studying public policy: Policy cycles and policy subsystems [Internet]. Oxford University Press Toronto; 1995 [cited 2017 Mar 8]. Available from: https://www.cambridge.org/core/services/aopcambridge-core/content/view/S0008423900007423.

60. Gilson L, Raphaely N. The terrain of health policy analysis in low and middle income countries: a review of published literature 1994-2007. Health Policy Plan. 2008;23:294-307.

61. Sabatier PA, Weible C. Theories of the Policy Process. Boulder: Westview Press; 2014.

62. Kingdon JW. How do issues get on public policy agendas? In: Wilson WJ, editor. Sociology and the Public Agenda. Newbury Park: SAGE Publications; 1993. p. 40-50.

63. Boussaguet $L$, Jacquot $S$, Ravinet P. Dictionnaire des politiques publiques. 4ème édition. Paris: Les Presses de Sciences Po; 2006

64. Abrokwah SO, Moser CM, Norton EC. The effect of social health insurance on prenatal care: the case of Ghana. Int J Health Care Finance Econ. 2014;14:385-406.

65. Adinma ED, Brian-D Adinma Jl, Obionu CC, Asuzu MC. Effect of government-community healthcare co-financing on maternal and child healthcare in Nigeria. West Afr J Med. 2011;30:35-41.

66. Ashir GM, Doctor HV, Afenyadu GY. Performance based financing and uptake of maternal and child health services in yobe sate, northern Nigeria. Glob. J. Health Sci. 2013;5:34-41.

67. Baird SJ, Garfein RS, McIntosh CT, Oezler B. Effect of a cash transfer programme for schooling on prevalence of HIV and herpes simplex type 2 in Malawi: a cluster randomised trial. Lancet. 2012;379:1320-9.

68. Binyaruka P, Patouillard E, Powell-Jackson T, Greco G, Maestad O, Borghi J. Effect of Paying for Performance on Utilisation, Quality, and User Costs of Health Services in Tanzania: A Controlled Before and After Study. PLoS One. 2015;10:e0135013.

69. Brugiavini A, Pace N. Extending health insurance in Ghana: effects of the National Health Insurance Scheme on maternity care. Health Econ Rev. 2015;6:7.

70. Davis B, Gaarder M, Handa S, Yablonski J. Evaluating the impact of cash transfer programmes in sub-Saharan Africa: an introduction to the special issue. J Dev Eff. 2012;4:1-8.

71. Dzakpasu S, Soremekun S, Manu A, ten Asbroek G, Tawiah C, Hurt L, et al. Impact of Free Delivery Care on Health Facility Delivery and Insurance Coverage in Ghana's Brong Ahafo Region. PLoS One. 2012;7:e49430.

72. Johnson FA, Frempong-Ainguah F, Padmadas SS. Two decades of maternity care fee exemption policies in Ghana: have they benefited the poor? Health Policy Plan. 2016;31:46-55.

73. Kivumbi GW, Kintu F. Exemptions and waivers from cost sharing: ineffective safety nets in decentralized districts in Uganda. Health Policy Plan. 2002;17:64-71.

74. Ridde V, Diarra A, Moha M. User fees abolition policy in Niger: Comparing the under five years exemption implementation in two districts. Health Policy. 2011;99:219-25.

75. Van den Heever AM. The role of insurance in the achievement of universal coverage within a developing country context: South Africa as a case study. BMC Public Health. 2012;12 Suppl 1:S5.
76. Atun R, Kazatchkine M. Promoting Country Ownership and Stewardship of Health Programs: The Global Fund Experience. Jaids-J Acquir Immune Defic Syndr. 2009;52:567-8.

77. Eboko F, Hane F, Demange É, Faye SL. Gouvernance et sida en Afrique: instruments de l'action publique internationale, l'exemple du Fonds mondial. Mondes En Dév. 2015:59-74.

78. Katz I, Glandon D, Wong W, Kargbo B, Ombam R, Singh S, et al. Lessons learned from stakeholder-driven sustainability analysis of six national HIV programmes. Health Policy Plan. 2014;29:379-87.

79. Thwing JI, Perry RT, Townes DA, Diouf MB, Ndiaye S, Thior M. Success of Senegal's first nationwide distribution of long-lasting insecticide-treated nets to children under five - contribution toward universal coverage. Malar J. 2011;10:86-93.

80. West PA, Protopopoff N, Rowland MW, Kirby MJ, Oxborough RM, Mosha FW, et al. Evaluation of a national universal coverage campaign of long-lasting insecticidal nets in a rural district in north-west Tanzania. Malar J. 2012;11:273.

81. Yawson AE, Dako-Gyeke P, Addo SA, Dornoo BT, Addo NA. Utilization of HIV Testing and Counseling in Ghana: Implications for Universal Coverage. Afr J Reprod Health. 2014;18:144-54

82. Kirigia J, Zere E, Akazili J. National health financing policy in Eritrea: a survey of preliminary considerations. BMC Int. Health Hum. Rights. 2012;12:16.

83. Musango L, Orem JN, Elovainio R, Kirigia J. Moving from ideas to action developing health financing systems towards universal coverage in Africa. BMC Int Health Hum Rights. 2012;12:30.

84. Sambo LG, Kirigia JM, Ki-Zerbo G. Health financing in Africa: overview of a dialogue among high level policy makers. BMC Proc. 2011;5(Suppl 5):S2.

85. Sambo LG, Kirigia JM, Orem JN. Health financing in the African Region: 2000-2009 data analysis. Int Arch Med. 2013;6:10

86. Sambo LG, Kirigia JM. Investing in health systems for universal health coverage in Africa. Bmc Int. Health Hum. Rights. 2014;14:28.

87. Uzochukwu BSC, Ughasoro MD, Etiaba E, Okwuosa C, Envuladu E, Onwujekwe OE. Health care financing in Nigeria: Implications for achieving universal health coverage. Niger J Clin Pract. 2015;18:437-44.

88. Abiiro GA, Mclntyre D. Achieving universal health care coverage: Current debates in Ghana on covering those outside the formal sector. Bmc Int Health Hum Rights. 2012;12:25.

89. Abiiro GA, Mclntyre D. Universal financial protection through National Health Insurance: a stakeholder analysis of the proposed one-time premium payment policy in Ghana. Health Policy Plan. 2013;28:263-78.

90. Adewole DA, Adebayo AM, Udeh El, Shaahu VN, Dairo MD. Payment for Health Care and Perception of the National Health Insurance Scheme in a Rural Area in Southwest Nigeria. Am J Trop Med Hyg. 2015;93:648-54.

91. Fenny AP, Enemark U, Asante FA, Hansen KS. Patient satisfaction with primary health care - a comparison between the insured and non-insured under the National Health Insurance Policy in Ghana. Glob J Health Sci. 2014;6:9-21.

92. Shisana O, Rehle T, Louw J, Zungu-Dirwayi N, Dana P, Rispel L. Public perceptions on national health insurance: moving towards universal health coverage in South Africa. South Afr Med J Suid-Afr Tydskr Vir Geneeskd. 2006;96:814-8.

93. Ankrah Odame E, Akweongo P, Yankah B, Asenso-Boadi F, Agyepong I. Sustainability of recurrent expenditure on public social welfare programmes: expenditure analysis of the free maternal care programme of the Ghana National Health Insurance Scheme. Health Policy Plan. 2014;29:271-9.

94. Munge K, Briggs AH. The progressivity of health-care financing in Kenya. Health Policy Plan. 2014:29:912-20.

95. Reeves A, Gourtsoyannis Y, Basu S, McCoy D, McKee M, Stuckler D. Financing universal health coverage-effects of alternative tax structures on public health systems: cross-national modelling in 89 low-income and middle-income countries. Lancet. 2015;386:274-80.

96. Mladovsky P, Ndiaye P, Ndiaye A, Criel B. The impact of stakeholder values and power relations on community-based health insurance coverage: qualitative evidence from three Senegalese case studies. Health Policy Plan. 2014;30:768-81.

97. Mtei G, Makawia S, Masanja H. Monitoring and Evaluating Progress towards Universal Health Coverage in Tanzania. PLoS Med. 2014;11:e1001698.

98. Richard V. Financement communautaire de la santé en Afrique : Les mutuelles de santé. Médecine Trop. 2005;65:87-90.

99. Saksena P, Antunes AF, Xu K, Musango L, Carrin G. Mutual health insurance in Rwanda: evidence on access to care and financial risk protection. Health Policy Amst Neth. 2011;99:203-9.

100. Sossa T. Couverture, financement et exclusion : I'assurance maladie en Afrique. Finance Bien Commun. 2011;37-38:94-103. 
101. Witter S. Service- and population-based exemptions: are these the way forward for equity and efficiency in health financing in low-income countries? Adv Health Econ Health Serv Res. 2009;21:251-88.

102. Adewole DA. The impact of political institution and structure on health policy making and implementation: Nigeria as a case study. Afr J Med Med Sci. 2015:44:101-5.

103. Naidoo S. The South African national health insurance: a revolution in health-care delivery! J Public Health. 2012;34:149-50.

104. Shiner A. Shaping health care in Tanzania-who's pulling the strings? Lancet. 2003;362:829-30

105. Agyepong IA, Adjei S. Public social policy development and implementation: a case study of the Ghana National Health Insurance scheme. Health Policy Plan. 2008;23:150-60.

106. Kusi-Ampofo O, Church J, Conteh C, Heinmiller BT. Resistance and Change: A Multiple Streams Approach to Understanding Health Policy Making in Ghana. J Health Polit Policy Law. 2015;40:195-219.

107. Meessen B, Hercot D, Noirhomme M, Ridde V, Tibouti A, Tashobya CK, et al. Removing user fees in the health sector: a review of policy processes in six sub-Saharan African countries. Health Policy Plan. 2011;26:ii16-29.

108. Seddoh A, Akor SA. Policy initiation and political levers in health policy: lessons from Ghana's health insurance. BMC Public Health. 2012;12:S10.

109. Witter S, Garshong B, Ridde V. An exploratory study of the policy process and early implementation of the free NHIS coverage for pregnant women in Ghana. Int J Equity Health. 2013;12:16.

110. Ye M, Aninanya GA, Sie A, Kakoko DCV, Chatio S, Kagone M, et al. Establishing sustainable performance-based incentive schemes: views of rural health workers from qualitative research in three sub-Saharan African countries. Rural Remote Health. 2014;14:2681.

111. Meda ZC, Konate L, Ouedraogo H, Sanou M, Hercot D, Sombie I. Leadership and vision in the improvement of universal health care coverage in lowincome countries. Sante Montrouge Fr. 2011;21:178-84.

112. Olivier de Sardan J-P, Ridde V. L'exemption de paiement des soins au Burkina Faso, Mali et Niger: Les contradictions des politiques publiques. Afr Contemp. 2012;243:11.

113. Ridde V, Richard F, Bicaba A, Queuille L, Conombo G. The national subsidy for deliveries and emergency obstetric care in Burkina Faso. Health Policy Plan. 2011;26:ii30-40.

114. Ridde V, Queuille L, Kafando Y, Robert E. Transversal analysis of public policies on user fees exemptions in six West African countries. BMC Health Serv Res. 2012;12:409.

115. Basaza RK, O'Connell TS, Chapcakova I. Players and processes behind the national health insurance scheme: a case study of Uganda. BMC Health Serv Res. 2013;13:357

116. Gilson L, Erasmus E, Borghi J, Macha J, Kamuzora P, Mtei G. Using stakeholder analysis to support moves towards universal coverage: lessons from the SHIELD project. Health Policy Plan. 2012;27:i64-76.

117. Kajula PW, Kintu F, Barugahare J, Neema S. Political analysis of rapid change in Uganda's health financing policy and consequences on service delivery for malaria control. Int J Health Plann Manag. 2004;19:S133-53.

118. Onoka CA, Hanson K, Hanefeld J. Towards universal coverage: a policy analysis of the development of the National Health Insurance Scheme in Nigeria. Health Policy Plan. 2014;30:1105-17.

119. Gilson L, Doherty J, Lake S, Mclntyre D, Mwikisa C, Thomas S. The SAZA study: implementing health financing reform in South Africa and Zambia. Health Policy Plan. 2003;18:31-46.

120. Peerenboom PB, Basenya O, Bossuyt M, Ndayishimiye J, Ntakarutimana L, van de Weerd J. La bonne gouvernance dans la réforme du financement du système de santé au Burundi. Santé Publique. 2014;26:229-40.

121. Falisse J-B, Ndayishimiye J, Kamenyero V, Bossuyt M. Performance-based financing in the context of selective free health-care: an evaluation of its effects on the use of primary health-care services in Burundi using routine data. Health Policy Plan. 2014;30:1251-60.

122. Ponsar F, Van Herp M, Zachariah R, Gerard S, Philips M, Jouquet G. Abolishing user fees for children and pregnant women trebled uptake of malaria-related interventions in Kangaba, Mali. Health Policy Plan. 2011;26:ii72-83.

123. Rusa L, Ngirabega J de D, Janssen W, Van Bastelaere S, Porignon D, Vandenbulcke W. Performance-based financing for better quality of services in Rwandan health centres: 3-year experience. Tropical Med Int Health. 2009;14:830-837.

124. Falisse J-B, Meessen B, Ndayishimiye J, Bossuyt M. Community participation and voice mechanisms under performance-based financing schemes in Burundi. Trop Med Int Health TM IH. 2012;17:674-82.
125. Nyandekwe M, Nzayirambaho M, Baptiste KJ. Universal health coverage in Rwanda: dream or reality. Pan Afr Med J. 2014;17:232.

126. Torbica A, De Allegri M, Belemsaga D, Medina-Lara A, Ridde V. What criteria guide national entrepreneurs' policy decisions on user fee removal for maternal health care services? Use of a best-worst scaling choice experiment in West Africa. J Health Serv Res Policy. 2014;19:208-15.

127. Nabyonga-Orem J, Ssengooba F, Mijumbi R, Tashobya CK, Marchal B, Criel B. Uptake of evidence in policy development: the case of user fees for health care in public health facilities in Uganda. BMC Health Serv Res. 2014;14:639.

128. Paul E, Sossouhounto N, Eclou DS. Local stakeholders' perceptions about the introduction of performance-based financing in Benin: a case study in two health districts. Int J Health Policy Manag. 2014;3:207-14.

129. Fox S, Witter S, Wylde E, Mafuta E, Lievens T. Paying health workers for performance in a fragmented, fragile state: reflections from Katanga Province, Democratic Republic of Congo. Health Policy Plan. 2014;29:96-105.

130. Atim C. Second Conference of the African Health Economics and Policy Association: towards universal healthcare coverage in Africa. Expert Rev Pharmacoecon Outcomes Res. 2011;11:267-71.

131. McIntyre D, Ranson MK, Aulakh BK, Honda A. Promoting universal financial protection: evidence from seven low- and middle-income countries on factors facilitating or hindering progress. Health Res. Policy Syst. 2013;11:36.

132. Chimhutu V, Lindkvist I, Lange S. When incentives work too well: locally implemented pay for performance (P4P) and adverse sanctions towards home birth in Tanzania - a qualitative study. BMC Health Serv Res. 2014;14:23.

133. Chirwa ML, Kazanga I, Faedo G, Thomas S. Promoting universal financial protection: contracting faith-based health facilities to expand access lessons learned from Malawi. Health Res Policy Syst. 2013;11:27.

134. Masiye F, Chitah BM, McIntyre D. From targeted exemptions to user fee abolition in health care: Experience from rural Zambia. Soc Sci Med. 2010;71:743-50.

135. Manitu SM, Meessen B, Lushimba MM, Macq J. Le débat autour du financement basé sur la performance en Afrique subsaharienne : analyse de la nature des tensions. Santé Publique. 2015;27:117-28.

136. Shroff ZC, Tran N, Meessen B, Bigdeli M, Ghaffar A. Taking Results-Based Financing from Scheme to System. Health Syst. Reform. 2017;3:69-73.

137. Shroff ZC, Bigdeli M, Meessen B. From Scheme to System (Part 2): Findings from Ten Countries on the Policy Evolution of Results-Based Financing in Health Systems. Health Syst. Reform. 2017;3:137-47.

138. Witter S, Fretheim A, Kessy FL, Lindahl AK. Paying for performance to improve the delivery of health interventions in low- and middle-income countries. Cochrane Database Syst Rev. 2012;2:CD007899.

139. Andriamahefazafy F. Place des bailleurs de fonds dans le système de l'aide au développement: le cas du Plan national d'actions environnementales de Madagascar. Cahier du GEMDEV. 2005;30:45-7.

140. Chimhutu V, Tjomsland M, Songstad NG, Mrisho M, Moland KM. Introducing payment for performance in the health sector of Tanzania- the policy process. Glob Health. 2015;11:38.

141. International Monetary Fund. Factsheet - Debt Relief Under the Heavily Indebted Poor Countries (HIPC) Initiative [Internet]. IMF. 2015 [cited 2015 May 10]. Available from: http://www.imf.org/external/np/exr/facts/hipc.htm.

142. Witter S, Adjei S. Start-stop funding, its causes and consequences: a case study of the delivery exemptions policy in Ghana. Int J Health Plann Manag. 2007;22:133-43.

143. Weyland K. The diffusion of innovations: how cognitive heuristics shaped Bolivia's pension reform. Comp Polit. 2005;38:21-42.

144. Foli R, Béland D. International Organizations and Ideas About Poverty in Sub-Saharan Africa. Poverty Public Policy. 2014;6:3-23.

145. Béland, Daniel, and Mitchell Orenstein. How Do Transnational Policy Actors Matter?. Annual Meeting of the Research Committee. 2009. p. 19. Available from: http://s3.amazonaws.com/academia.edu.documents/30768290/belandd_rc192009.pdf?AWSAccessKeyld=AKIAIWOWYYGZ2Y53UL3A\&Expires= $1497627824 \&$ Signature $=\% 2 B n 5 t 7$ CrfNgCSZ2Xh9T7YgN1xCUc\%3D\&responsecontentdisposition=inline\%3B\%20filename\%3DHow_Do_Transnational_ Policy_Actors_Matte.pdf.

146. Foli R. Transnational actors and anti-poverty policymaking in Ghana : An ideational perspective [Internet]. 2015. cited 2016 Oct 19. Available from: https://ecommons.usask.ca/handle/10388/ETD-2016-06-2257.

147. Ridde V. Politiques publiques de santé, logiques d'acteurs et ordre négocié au Burkina Faso. Cah Détudes Afr. 2011;201:115-43.

148. Ridde V. From institutionalization of user fees to their abolition in West Africa: a story of pilot projects and public policies. BMC Health Serv Res. 2015;15 Suppl 3:S6. 
149. Thomas S, Gilson L. Actor management in the development of health financing reform: health insurance in South Africa, 1994-1999. Health Policy Plan. 2004;19:279-91.

150. Kiendrébéogo JA, Berthé A, Yonli L, Béchir M, Shroff ZC, Meessen B. Why Performance-Based Financing in Chad Failed to Emerge on the National Policy Agenda. Health Syst Reform. 2017;0:00.

151. Dieleman JL, Schneider MT, Haakenstad A, Singh L, Sadat N, Birger M, et al. Development assistance for health: past trends, associations, and the future of international financial flows for health. Lancet. 2016;387:2536-44.

152. Hodal K. Aid reforms could see big increase in private sector subsidies. The Guardian [Internet]. 2016 Oct 10 [cited 2016 Oct 19]; Available from: https://www.theguardian.com/global-development/2016/oct/10/aidreforms-could-see-big-increase-in-private-sector-subsidies.

153. Janes CR, Corbett KK. Anthropology and Global Health. Annu Rev Anthropol. 2009:38:167-83.

154. Whitfield L. Aid's political consequences: the embedded aid system in Ghana. [Internet] GEG Working Paper; 2006 [cited 2016 Oct 18]. Available from: http://www.geg.ox.ac.uk/sites/geg/files/GEG\%20WP\%202006_ 24\%20Aid\%27s\%20political\%20consequences\%20\%20the\%20embedded\%20aid\%20system\%20-\%20Lindsay\%20Whitfield.pdf.

155. Koehlmoos T, Rashid M, Rahman Z, Cravioto A, Hanney S. Understanding the Role of Evidence in Policy Making in Bangladesh Report 1: An Analysis of Interviews with Health Sector Decision Makers. Bridg. Know- Gap Strateg. Enhance Capacity Apply Health Policy Syst Res Evid-Inf Policy Mak. Bangladesh [Internet]. 2009 [cited 2016 Oct 18]; Available from: http://www. who.int/entity/alliance-hpsr/projects/alliancehpsr_snpreport1 bang09.pdf.

156. Robert E, Ridde V. Global health actors no longer in favor of user fees: a documentary study. Glob Health. 2013;9:29.

157. Turcotte-Tremblay A-M, Spagnolo J, De Allegri M, Ridde V. Does performance-based financing increase value for money in low- and middleincome countries? A systematic review Health Econ Rev. 2016;6:30.

158. Moher D, Liberati A, Tetzlaff J, Altman DG, PRISMA Group. Preferred reporting items for systematic reviews and meta-analyses: the PRISMA statement. Ann Intern Med. 2009;151:264-9. W64

\section{Submit your next manuscript to BioMed Central and we will help you at every step:}

- We accept pre-submission inquiries

- Our selector tool helps you to find the most relevant journal

- We provide round the clock customer support

- Convenient online submission

- Thorough peer review

- Inclusion in PubMed and all major indexing services

- Maximum visibility for your research

Submit your manuscript at www biomedcentral.com/submit 